\title{
第59回日本内科学会講演会 (1962年)
}

\section{シンポジウム癌の診断}

（3）特殊責性物質検索による癌診断

\author{
鹿児鳥大学教授 \\ 佐藤八郎 \\ 鹿児島大学講師
}

柚木一雄

\section{I. 序 論}

癌の生物学的診断法は, Tumor and Host Relationの立場から，癌の存在を推測する特異な 診断法である，その目的とするところは，局所癌 の診断よりも，むしろ癌状態の診断であり，癌に よる生体反応を判定することである、嵒を単なる 局所疾息とする古典的概念注次第に改革を要請 され，現今では，癌を全身性疾患として理解する 方向に大きく移り変りつ〉ある. 発癌過程の生化 学的変化を追究したわれわれの成續も，発癌が単 なる局所条件によつて成立するもので注なく，全 身的な発癌条件を必要とする事実を示している。 また，癌唯生体内に存在する場合，広く全身性に 系統的変化を現わしてくることは最早動かし難い 事実で，癌診療の立埸加らもこの現象は見逃すこ とはできない，現代医学は，癌を全身疾患として 理解すへき事実を集積しつ〉あるといえる。か る観点方ら，癌反店注全身疾意としての癌を把握 する有力な手段であるが，癌の臨庥的立場から は，現在のところ，癌反応は補助䛦断法的位置に とぐまらざるを得ない，現在の診療技術を以てし ては，癌の局所疾息的意義が全身疾㭧的意義を遥 かに凌駕しているからである。しかし乍ら，癌の 本質上，局所診断法と癌状態判定法としての癌反 応は共存的に車立すへきものと信ずる。

従来，癌に於子名系統的广変化としていくつ加 の現象がとり上げられ，癌反応に利用されて来た

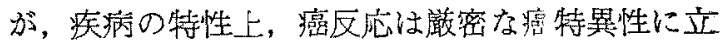
脚せ秝ばならぬことになる。この意味で, 癌特異 代謝の究明に俟つところが大きく，今後の発展に 期待するところが多いといわ放ばならない，われ われは，癌特異代謝の究明を続け，癌に於ける采 統的变化の原因物質として, 癌腫毒の存在を提唱 している、癌腫毒が厳密な癌特異性を有するとす れば，その檢索は癌状態の判定に役立つところが 大きい之言わねばならない，以下，癌腫毒の特異 性，その検索法，癌診断に対する癌腫毒検索の意 義等について検討する。

\section{II. 実験材料および実験方法}

人癌組織忬よで患者尿より癌腫毒分画を抽出 し，その生物作用扔よび免疫学的性状について㭘 討した。生物作用としては，癌腫毒の多面的な 作用中䀒力タラーゼ減少活性に注目し，尿癌腫毒 今画の䀒カタラーゼ減少活性を診所に利用した。

また，免疫学的には，カオリン吸着尿癌腫毒分画 々抗癌血清との凝集及忘を診断に利用した。

1. 癌腫毒分画抽出法

人癌組織抢よび患者尿を材料とし，以下の方法 で癌腫毒分画を抽出した。

a) B成分抽出法

人癌組織を材料とする埸合は組織乳剂に3 倍量 の生理食塩水を加えて, $70^{\circ} \mathrm{C}, 30$ 分間加熱し, 漟 過, 法液に第 1 表の如き力オリン吸着法を奏施す

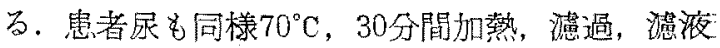


第 1 表. 癌腫愫抽出法（カオリン吸着法）

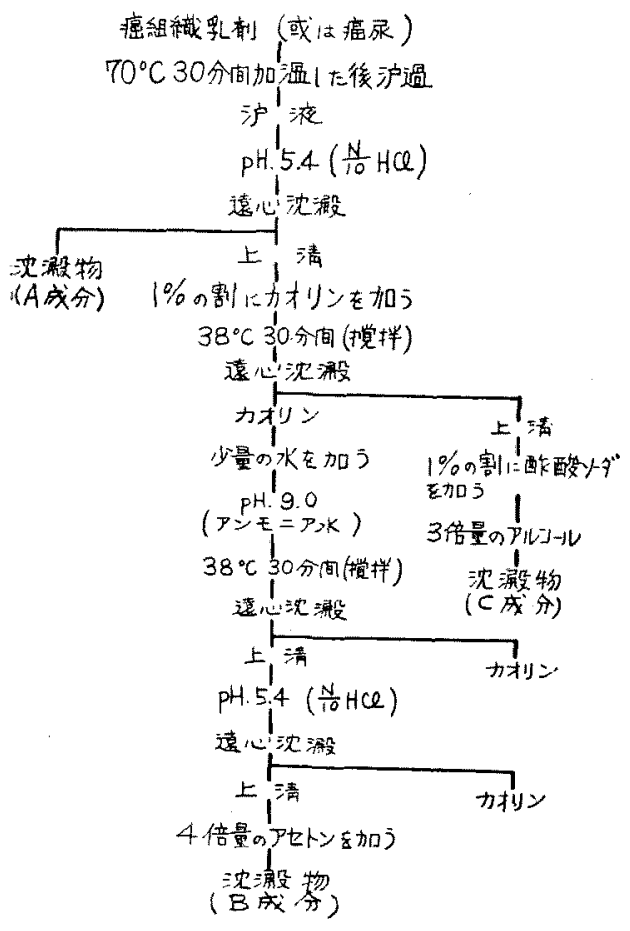

のカオリン吸着法を行ない，B成分を抽出した。

b) PII 分画抽出法

人癌組織のアセトン乾燥粉末に，2倍量のアセ

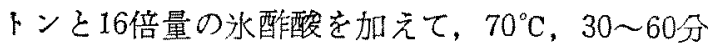
間，加熱抽出する。洃液に $1 / 200$ 量の $5 \mathrm{M} \mathrm{NaCl}$ と1/2量のアセトンを加え，水空に12時間放置する と白色沈澱を生ずる。沈搌を滤過除去し，惯液に 等量のエーテルを加えると白色沈澱を生ずる，沈

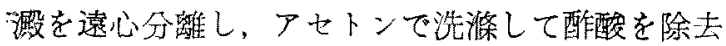
した後乾燥せしめ, 粗癌腫毒 PII 分画とする。

c) CM分画抽出法

PII 分画の $0.1 \mathrm{~N}$ 酰酸溶液（1000cC）に，H型 活性 Carboxy-methyl cellulose $2 \mathrm{~g}$ 范加え, ? グネティック・スタイアラーで 3 時間攪汼し，活 性物質を吸着せしめる。七ルローズを sinter glass filter 上に集め，0.1 N酶酸，次いで蒸? 水で洗滌する。セルローズを再び少量の $0.1 \mathrm{~N}$ $\mathrm{HCl}$ に㲘濁し，2㭙間攪汼，有効因子を溶離す，

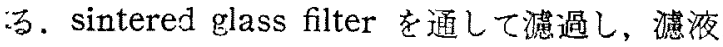

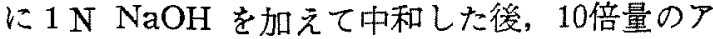
セトンを加えて，組織CM分画を沈淈せしめる。

㭧者尿を材料とする場合には，尿1000ccに水酭 酸 $6.7 \mathrm{Cc}$ を加えて酸性となし，濾過，滤過尿に上 記々同様のCM-cellulose吸着法定実施し，尿 CM 分画を拧出する。

2. 癌腫毒分画活性検定法

癌腫毒分画の㭘定量を蒸留水 $1 \mathrm{CC}$ 溶解，体重 $15 \mathrm{~g}$ 前娞のdd-采堆マウスの腹腔内に注入し，24 時間後に旰カタラーゼを測定した。検定法の詳細 は，トキソホルモン研究玨の毒性物質活性検定法 の試案に準じて実施した。

䀒カタラーゼ活性は Euler-Josephson 法によ り測定，検定マウスの䀒カタラーゼの正常マウス 䀒カタラーゼに対する減少率を以て, 癌腫毒活性 の唒を現わした。

䀒カタラーゼ減少高 $=\frac{\mathrm{B}}{\mathrm{A}-\mathrm{B}} \times 100 \%$

但し，A注同時に測定した正常マウスの䀒カタ ラーゼ活性値

Вは被検マウスの䀒カタラーゼ活性值

3. 癌腫毒の免疫学的検索

組織 $\mathrm{B}$ 成分と尿 $\mathrm{B}$ 成分の免疫学的性状を抗癌血 清々の沈降反応によつて検討し，尿癌腫毒の免疫 学的検索法の可能性を追究した。

a) 抗血清作製法

迌胃癌組織乳剂家秉免疫血清

人胃癌組織の 5 倍生理的食塩水加乳偊（ $0.5 \%$ カルボール加）を作り，その3〜5ccずつを8〜 10回, 家東の耳静脈内に注射し，最終注身より 7

〜8日後に埰血，血清を分離する。 抗胃潰瘍組織乳剂家兔免疫血清

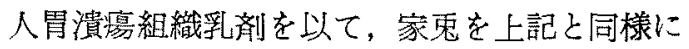
免疫し，抗潰嗐血清を作製する。

抗A B型人血球家䨟免疫血清

A B型人血球の $10 \%$ 生理的食塩水浮遊液を作 り，上記と同様，家电を免疫する。

抗胃癌B成分家雨免疫血清

胃癌組織B成分の $1 \%$ 生理的食塩水溶液を作 
り，その3〜 5 cc宛を，隔日に，7〜10回，家

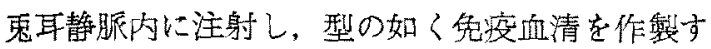
る.

\section{b) 吸収試験実施法}

抗血清心吸收物を加え， $37^{\circ} \mathrm{C} 2$ 時間䀣邲器内に 入れ，時マ振盓する，次いで氷空中に一尽夜放置 後，遠心沈澱してその上清を実験に使用した。

4. 癌腫毒の精製分離

人癌組織より抽出したP PII 分画，或いは CM分 画を材料とし, Amberlite XE-64, Column chromatography による精艎分離を試みた。

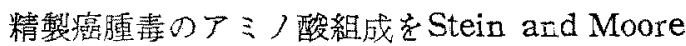
の方法により，リポイド組成を Silicic acid chromatographyにより，N末端アミり酸を Sanger and TrompsonのDN P法により検討した。

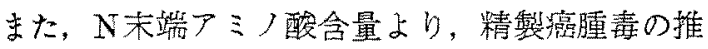
定最小分子量を計算した。

\section{III. 実験結果}

1. 担癌体に於注る䀒力タラーゼの変化

DAB飼着ラッテの畈カタラーゼは，䀒癌発生 とともに著減する。吉田肉腫腹腔内移植マウスで は，はじめ $1 〜 2$ 日間は腫湟細胞の增殖を認める が, 直ちに自然治壆を来たし, 腫福細胞は消失す る、䀒力タラーゼは，腫場增殖とともに著減し，

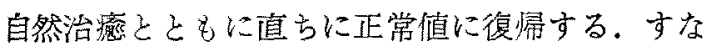
わち，䀒力タラーゼ減少㹥腫場組織の特徴である とともに，腫演に本質的な全身変化の一つといえ る. 煺つて, 㿋腫毒の生物学的活性検定法に, 䀒 カタラーゼ隇少効果を目標とすることができる。

2. 癌腫毒の生物学的活性

人癌組織 B成分㥩著明な䀒力タラーゼ減少活性 を示し，非癌組織B成分にはその作用証めなか つた。亲た，尿B成分も，癌患者尿を材料已する 時にの加力夕ラーゼ減少活性を示した。す病わ ち，癌跣毒が癌組織で生産され，終局的には尿中 に排泄されることを示しており，尿中癌腫毒活性 を梌索することにより，癌状熊を判定し得る可能 性を暗示するものである。

人癌組織より抽出したPII 分画も，20mg〜10 m
で著明な肝カタラーゼ活性を示したが，これより CM-cellulose 吸着法で抽出したCM分画は更に 高度の癌腫毒活性を有することがわかった。

癌息者尿より抽出した CM分画を，B成分とほ 浔同等の旰力タラ一ゼ減少活性を示し，原中癌腫 毒の検索法に利用しうることがわかつた。

以上の如く，癌組織及び癌尿上り，问様な抽出 法で，活ぐ同様な肝カタラーゼ減少活性を有する 物質の得られることは，癌組䅧及び癌尿中の有效 因子が類似した化学性状を有することを暗示す る。また，癌の場合と同様な姏理によつて非癌組 織及び非癌层から抽出される物質に旰力タラーゼ 減少活性を認めなかつたことは，非癌では䀒カタ ラーゼ減少因子の欠如すること，或いは，存在す るにしても非常な徽量に過ぎないことを示してい る。すなわち, 嵒腫毒は癌特異性を有する物質, 或いは，それに近い存在であるといえるようであ る，従つて，尿中の癌腫毒を把握することは，癌 状態の判定に有力な手段となり得るであるう.

3. 尿中癌腫毒分画の旰为ラーゼ減少活性検 定による癌䛦断の試み

前述の基礎実験より，尿癌腫毒の検索に，䀒力 タラーゼ減少效果を利用しうることがわかつた。 よつて，以下の如き方法を以て癌診断の可能性を 検討した。

試験に使用する癌腫毒分画は，原則として被検 息者尿 200ccより抽出したB成分，或いは，CM 分画老使用し，二れ蒸留水 $1 \mathrm{Cc}$ に溶解してマウ スの腹腔内に注入する．24時間後旰力タラーゼを 測定し，正常マウスの旰カタラーゼと比較じて， 被検マウスの䀒カタラーゼ減少摔を以て癌腫毒活 性を現わすこ上は前述の通りである。しかし仵ら， 正常マウスの盯力タラーゼも決して一定せず，相: 当な variation を示し，殊に等的変動の著し いことが，正常值の stardard 決定する上に 非常な障害となり，また，癌診断に本法を利用す る上の最大の弱点となる。よつて，癌腫毒分画の 活性検定每に，control として正常マウス $2 \sim 3$ 匹の肝カタラーゼを測定し，その平均值を正常値 
の standardとして使用することにした。

a）尿 B成分の癌腫毒活性

悪性腫演尿99例，対膘疾患尿53例につき，その B成分の䀒カタラーゼ減少活性を測定した成績は 第 1，2図の如くである。すなわ，悪性腫演で 怆, $40 \%$ 以上の減少効果を示すもの $64.6 \%, 30 \%$ 以 上の減少示すもの $82.8 \%, 20 \%$ 以の減少を示

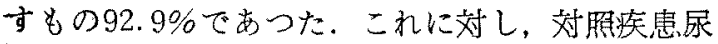

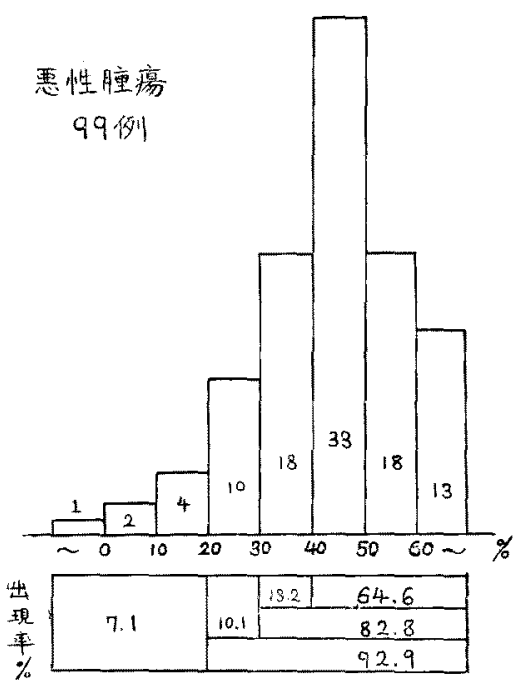

第1 图。尿 B 成分の肧カタラーゼ減少活性
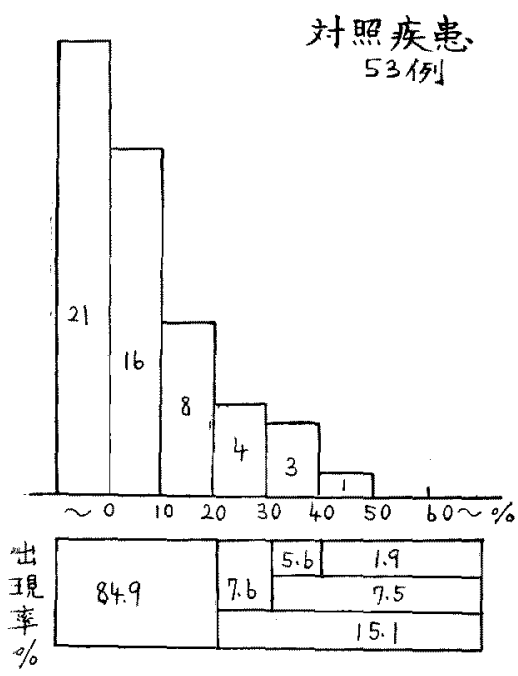

第 2 図。尿B成分の旰カタラーゼ減少活性
では，40\%以上の減少を示すもの $1.9 \% ， 30 \%$ 以 上減少を示すもの $7.5 \%, 20 \%$ 以上減少を示すも の15.1\%であつた。

b）尿 CM分画の癌腫毒活性

悪性腫瘍尿60例，対照疾勨尿31例の CM分画に つき，その䀒カタラーゼ減少活性を測定した成績

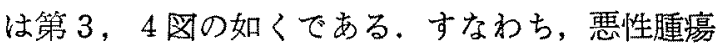
尿では，40\%以上減少を示すもの71.7\%，30\%以 上減少を示す， $81.7 \% ， 20 \%$ 以上減少を示すも の91.7\%であつた，対䐦疾患では，40\%以上の減 少を示したものなく，30\%以上の減少を示すもの $6.4 \% ， 20 \%$ 以上の堿少を示すもの19.3\%であつ た。

尿B成分も CM分画もほら゙同様な此率において 癌腫毒活性を示していることがわかる，従つて， 尿癌腫毒分画の䀒刃タラーゼ減少活性検定には, B成分を使用しても，CM分画を使用しても祫出 率に相違はないと話える。

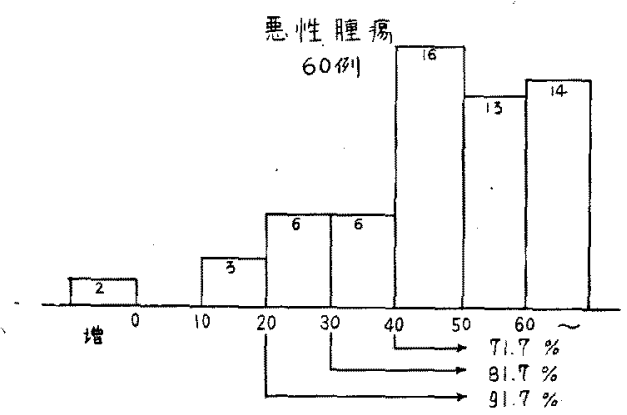

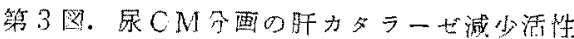

非悪性疾虫。

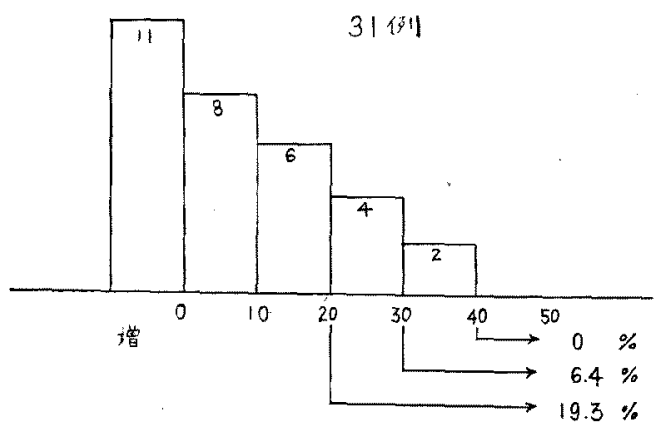

第 4 図. 永 CM分画の旰カタラーゼの減少活性 


\section{c) 癌腫要活性の判定規準}

以上の成續を総括すると，覀性腫璌尿 159 例 中, $40 \%$ 以上減少 $67.3 \% ， 30 \%$ 以上減少 $82.4 \%$, $20 \%$ 以上減少 $92.5 \%$, 对照矤患尿 84 例中，40\%以 上減少 $1.2 \% ， 30 \%$ 以上減少 $7.1 \%, 20 \%$ 以上減 少 $16.7 \%$ となる。よつて, 本反応を臨床検查に使 用する上の判定規準として，40\%以上の䀒カタラ 一ゼ減少活性を示した場合を井，30３9\%の減少 を示した場合を十, 20〜29\%減少を土, 20\%以下の 減少或いは堌加を示した場合を一とし，十以上を 示した場合を癌反応陽性と判定した. 臨床成績は, 第 2，3表の如く，悪性腫瘍 159例中，陽性率82.4

第 2 表. 悪性腫煬

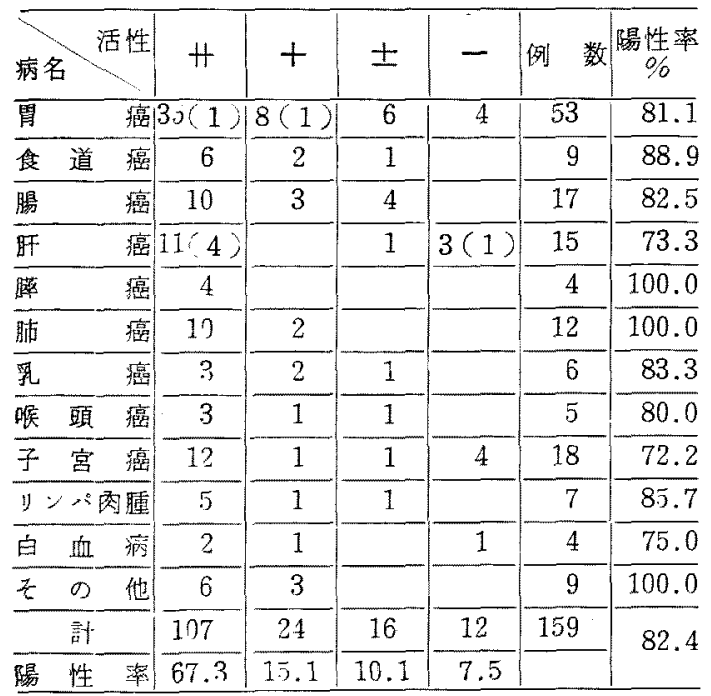

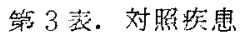

\begin{tabular}{|c|c|c|c|c|c|c|c|c|}
\hline \multicolumn{3}{|c|}{ 病名 活性 } & H & + & \pm & - & 例 数 & 陽性率 \\
\hline \multicolumn{3}{|c|}{ 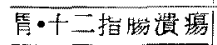 } & \multirow[b]{2}{*}{1} & \multirow{2}{*}{$\frac{2}{2}$} & \multirow{2}{*}{$\frac{5}{2}$} & 26 & 33 & 6.1 \\
\hline 刵 & 疾 & 患 & & & & 12 & 17 & 17.7 \\
\hline 瞒 & 疾 & 患 & & & & 2 & 2 & 0 \\
\hline 督 & 疾 & 患 & & & & 4 & 4 & 0 \\
\hline 續 & & 核 & & & & 12 & 12 & 0 \\
\hline 娃 & & 娠 & & & & 2 & 2 & 0 \\
\hline $\bar{z}$ & $\sigma$ & 他 & & & & 7 & 7 & 0 \\
\hline \multirow[t]{2}{*}{ 健 } & & 串 & & 1 & 1 & 5 & 7 & 14.3 \\
\hline & 棓 & & 1 & 5 & 8 & 70 & 84 & \multirow[t]{2}{*}{7.1} \\
\hline & $E$ & $\%$ & 1.2 & 5.9 & 9.6 & $\overline{83.3}$ & & \\
\hline
\end{tabular}

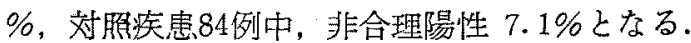

d) 術後尿中の癌腫毒活性

癌患者手術後の辰中癌腫毒の消長を検索してみ ると, 根治手術不成功例或いは転移巣の取り残し のあつたものでは，術直後には癌腫毒活性が却つ て上昇する傾向を示し，以後の経過を追つても長 く陰性化しない.これに対し，一応根治手術の成功 した例では，街後 $3 \sim 7$ 日で反応は陰性化する. しかし乍ら，断端に術後癌細胞浸潤を認めた例で も, 反応は術值後は陰転する傾向を示した。 か る現象は，早期癌診断に対する本反応の限界を示 唆するものと言える. 但し，汃る例も数週間後 には反空の陽転を来たすもので，疗癌腫毒活性の 消長は，予後判定の上にも参考をなることを示し ている，なお抗癌剤使用例で反応陰転を来たすも のは経験していない。

4. B成分及び抗癌血清の特異性

a) 癌B成分の抗原構造

抗胃癌組織乳绪免疫家需血清と組織B成分との 沈降反応を実施してみるに，胃癌組織B成分と胃 潰浧組織 B成分とは明らかな反応の場の相違を示 した。抗胃潰䄈組織乳剂家鬼免疫血清に対する両 B成分の反応の場には，殆に゙相違を認めることは できなかつた，また，抗胃癌組織B成分家鬼免疫 血清に対する両 $\mathrm{B}$ 成分の反芯の場には，著明な相 違が認められた。以上の事実は，胃癌組織B成分 は胃潰汮組織B成分に未知因子の加つたものであ ることを示唆する。

抗A B型人血球家雪免疫血清に対 L，A型胃癌 組織 $\mathrm{B}$ 成分は，沈降素価10倍以内の弱い反応を示 した，この抗血清を $\alpha \Theta 人$ 血清で吸收すると， 胃癌B成分に対する沈降素は消失する。二の事実 は，B成分中に嚾加乍ら型特暴抗原の含まれるこ と示している。

抗A B型人血球家鬼免疫血清に対し，O型胃癌 組織B成分は，沈降素価10倍以内の弱い反応者 すが， $\alpha \beta$ 人血清吸卭により反応は陰転する。，O 型胃癌組織中の型物韻の存在は一店否定し得るの で，この現像は，胃癌 B成分中に種属特異抗原の 存在を示すものと思われる。

抗胃癌組織B版分家鬼免疫血清中の型及び種属 特異抗体を組織 $\mathrm{C}$ 成分で紧取除去した後, 更に胃 
潰瘍組織 B成分で吸收しても，胃癌組織B成分の 沈降素洒慬かに減少するのみである。この事実 は, 胃癌組織 B成分中に僅加乍ら藏器特異抗原の 含まれることを示すとともに，大量の癌特異抗原 の含まれることを示している。

以上の結果から，胃癌組織B成分の抗原構造 は, 少量の型, 種属, 葴器特珙抗原と, 大量の癌 特異轨原加らなることがるかる。

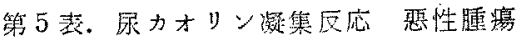

\begin{tabular}{|c|c|c|c|c|c|c|c|c|c|c|c|c|}
\hline 病 & 名 & 心 值 & - & 10 & 20 & 40 & 80 & 160 & 1320 & 640 & 計 & $\begin{array}{l}\text { 陽性率 } \\
(\%)\end{array}$ \\
\hline 胃 & & 癌 & 2 & 3 & 7 & 5 & 4 & 2 & 2 & 0 & 25 & 80 \\
\hline 金 & 道 & 癌 & & & 1 & 1 & 1 & & & & 3 & 100 \\
\hline 直 & 晹 & 癌 & & & & 1 & & 1 & & & 2 & 100 \\
\hline 瀮 & & 癌 & & & 1 & 4 & 3 & & & & 8 & 100 \\
\hline 㫜 & 管 & 癌 & & & 1 & & & & & & 3 & 100 \\
\hline 时 & & 癌 & & & 2 & 1 & 1 & & & & 4 & 100 \\
\hline 㲎 & & 癌 & 1 & & & 2 & & & & & 3 & 66 \\
\hline J & 黨 & 癌 & 1 & & 3 & 4 & 2 & 2 & & & 12 & 91 \\
\hline$E$ & 顎 & 癌 & 2 & & 1 & 2 & & 2 & & & 7 & 71 \\
\hline 喉 & 頭 & 癌 & & & & 2 & 1 & & & & 3 & 100 \\
\hline 1) & $y>0$ 肉 & 霾 & 1 & 1 & 1 & & & & & & 3 & 33 \\
\hline$z$ & $\infty$ & 他 & 2 & 2 & 6 & 2 & & 1 & & & 13 & 84 \\
\hline 例 & & 数 & 9 & 6 & 23 & 24 & 12 & 8 & 2 & & 84 & 82.1 \\
\hline
\end{tabular}

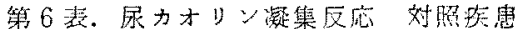

\begin{tabular}{|c|c|c|c|c|c|c|c|c|c|c|}
\hline 反底值 & - & 10 & 20 & 40 & 80 & 160 & 360 & 640 & 計 & $\begin{array}{c}\text { 隄性宰 } \\
(\%)\end{array}$ \\
\hline 简・十二指腸灒慯 & $y$ & 1 & 1 & & & & & & 11 & 9 \\
\hline 腸 炎 & 2 & & & & 1 & & & & 3 & 33 \\
\hline 肺疾 軎 & 7 & 2 & 1 & & & & & & 10 & 10 \\
\hline 霄 埃 麀 & 4 & 3 & 1 & & & & & & 8 & 12 \\
\hline 結 核 性 疾 虑 & 9 & & 2 & & & 1 & & & 12 & 25 \\
\hline 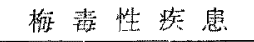 & 4 & & 1 & & & & & & 5 & 20 \\
\hline 病 & 3 & & & & & & & & 3 & \\
\hline 心血管系疾患 & 9 & 1 & & & & & & & 10 & 10 \\
\hline 康 & 10 & & . & & & & & & 10 & \\
\hline 例 & 57 & 7 & 6 & & 1 & 1 & & & 72 & 10.9 \\
\hline
\end{tabular}

抗胃癌組織 B成分家霌免疫血清に対し，癌尿 B 成分は，発癌目地の如何にかかわらず，320〜640

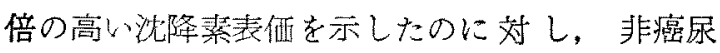
B成分は10倍前得の弱い反応を示寸に過ぎなかつ た。この事実は、癌尿B成分は癌組織B成分と抗
第 4 琵。层カタリン凝集反応蓝式

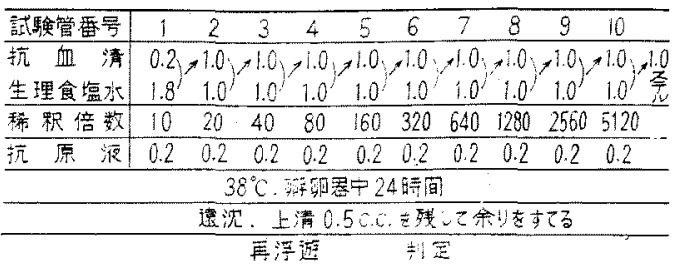


組織乳剤で家䖝を兔疫した場合，少量の型，種属 及び藏器特異抗体と，大量の澏特異抗体の應生さ れる事実を確㒛した。

以上の事実から，莯胃癌組織乳剂家需免疫血清 と癌尿 B成分の閒には，癌特異免疫反分が成立 し、これを癌反他に利用しうる可能性のあること がわかる。

\section{5. 尿カオリン凝集反匛}

尿B成分之抗癌血清の凂疫反成䒠施するに当 り，抗原はB成分をカオリンに吸着せしめたもの を，抗癌血清は抗胃癌組織乳剂家兔免疫血清を使 用し，カオリン粒子の㠜集を检した。

カオリン吸着抗原作製法：被积尿をB成分抽

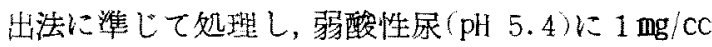
の割にカオリンを加无抗原を吸着せしめる。カオ

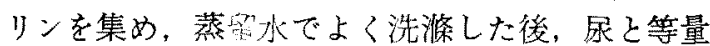
の生理食塩水にカォリンを浮避せしめ，これを抗 原液上して使用した。

尿カオリン凝集反纫術式：第 4 表の如く，緒 万民梅毒凝集反匛口街式に準じて実施した。

臨床検查成樍汁第 5，6表の如くである。非猫 尿でも10倍前後の弱い㠜集を示す場合が多いの で，20倍以上の㠜集を示した場合を癌反沈陽性上 判定する之，悪性腫瘍尿84例中陽性69例，㩐性率 $82.1 \%$, 対䐎疾息尿72例中，非合理陽性 8 例，陽 性率10.9\%であつた。

以上の如く，展中の癌尰毒は，畈カタラーゼ成 少活性を以てしても，免疫反応索以てしても検出 し得るものであるが，両反応の臨床成績は注メ゙同 様であり，癌腫毒検出法としての優劣は競い難い ものっようである。

6. 癌腫毒の精製及び精製涺腫毒の性状

PII 分画 Amberlite XE-64 column chromatography で分析し，高度有效物質 $\mathrm{TH}_{\varkappa}$ 分画を 分離したが，二れは更に，gradual elution technicにより，第5図の如く、三つの subfraction, $\mathrm{TH}_{2}-\mathrm{A}, \mathrm{TH}_{2}-\mathrm{B}$ 㧍よび $\mathrm{TH}_{2}-\mathrm{C}$ に分離さ机た。 これらの有效因子は何れも5 とで旰カタラ一セ減 少活性を示し，N末端に何れも arginine を有 する proteolipid で，推定最小分子量は $\mathrm{TH}_{2}-\mathrm{A}$ 5,700, $\mathrm{TH}_{2}-\mathrm{B} 4,200, \mathrm{TH}_{2}-\mathrm{C} 6,400$ であつた.

また，CM分画から Amberlite XE-64 colu$\mathrm{mn}$ chromatography, buffer, 1/100 M. sodium
第 5 図. Chromatographic pattern of crude cancer toxin (P.fraction).

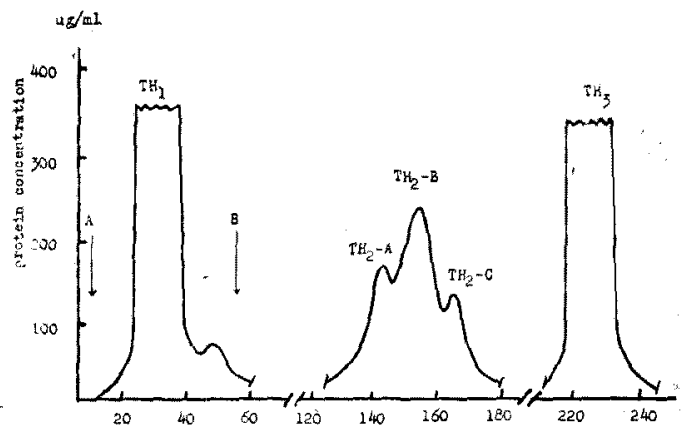

A: $\mathrm{M} / 10$ Glycine buffer at $\mathrm{pH} 9.40$.

$B$ : A gradient to more basic buffer by adding $0.1 \mathrm{~N} \mathrm{NaOH}$ throngh mixing chamber.

carbonate により，非透析型癌腫䍩 TH-C 2 分 画を分離したが、これは $0.5 \mathrm{mg} ゙$ 旰カタラーゼ娍 少活性を示した。更に，TH-C 2 分画のペプシン 部分分解虐物を上記と同様に好理することにより $\mathrm{TH}_{2}$ 分画を分離することができだ。

以上の事実は, 癌腫毒が種々の分子形熊で存在 し得る可能性を示して招り， $\mathrm{TH}_{2}$ 分画は癌腫毒 の基本活性型に近い物質である可能性がある。ま た，上記已同様なす法では，非癌組轼から $\mathrm{TH}_{2}$ 分 画を分離することは不可能であつた。すなわち，癌 睡毒が癌特異性物質である可能性を示している。

\section{IV. 結 語}

猫腫慧注，生物学的活性および免疫学的性状に おいて，癌特異性を示すのみならず，癌腫基 本活性型と思われる $\mathrm{TH}_{2}$ 分画は癌組織少らのみ 分離された，従つて，癌腫毒検索による癌診断 は，癌の本質に関連する特罢的な方法といえよ う、しかし年ら，本反応が癌細胞の産生する物質 自体を検索目標とする以上, 癌腫毒の生成, 体外 放出が検出の限界量に達せ权ばなら好ことにな る、こ〉に，本反応の早期癌診断に対する限界 が存在するといえよう。また， $\mathrm{TH}_{2}$ 分画の収量 は，癌組織の㻷類によりや〉相違するものである が、これは，癌の生物学的覀性度にも関連するも のと思われ，尿中癌腫毒の検出限界も，癌の進展 度のみならず, 生物学的性状にも左右されるとこ ろが大きいと思われる。

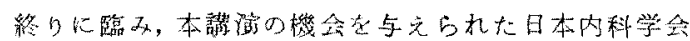

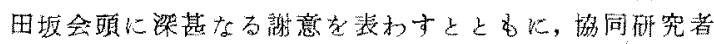
の譄兄に厚く御礼申上げる。 